\title{
System design of blood supply chain management based on Supplier Customer Relationship Management (SCRM) approach
}

\author{
Zuhdi Allamsyah and Agus Mansur* \\ Industrial Engineering, Islamic University of Indonesia, Yogyakarta, Indonesia
}

\begin{abstract}
Blood supply chain management is very complex system. By considering blood's demand that characterized as stochastic, therefore information and communication among stakeholders are considered as important cycle in supply chain. This research is objected to design interactive communication model based on information technology with android as platform to create effective customer-supplier relationship to support Customer Relationship Management or better known as CRM. The methods that suggested in designing its information system are Quality Function Deployment (QFD) approach, Kano Model and Morphological Chart. From mentioned methods, attributes of design and specification priorities of purposed android system technology design are established. Attributes of design will be adjusted with customers' requirements derived from customer voice that will further be integrated with technical responds in QFD. Technical responds will provide priorities on each design's attribute of android information system and will be forwarded to the specifications determination by using morphological chart. Later, work flow of design system will be generated by using Data Flow Diagram (DFD). The result of the research will demonstrate the design of information system technology based on android that already adjusted with the requirement of donors as means of communication between suppliers and customers in blood supply chain.
\end{abstract}

\section{Introduction}

Blood is a vulnerable commodity yet a vital transport system component to every person. The number of minimum requirement of blood in Indonesia was counted around 5,1 million blood packs per year or equal to $2 \%$ of total Indonesian residences. Until recently, it only covers 4,1 million blood packs sourced from 2,7 million donations, in which $87,74 \%$ of them are derived from voluntary blood donation [1]. The fact there was the imbalance supply and demand in DIY province [2]. Generally, worldwide, there are hospitals that suffer from insufficiency of blood stock, hence they require proper management [3]. The source of blood unavailability is the stochastic products' demand. While, only 5\% of population that consider as proper as blood's donors [4]. The scarcity of blood also emerged by the stochastic number of donors and/or the blood's stocks that are stored in the blood bank [5].

As the efforts in improving good service to customers, PMI DIY provides SMS gateway service to deliver information about blood's stock, reminder to conduct the donation and various events of blood donation. This service is expected to maximize the information distribution from PMI to customers. Nevertheless, this SMS gateway service still covers several shortages, for instance, it only could deliver information based on text that apparently will be one of the causes of information retardation. The availability of information system has effect on its user's performance in accessing the information [6]. Appropriate information system can possibly facilitate two-way communication for better information sharing. Information sharing and information quality on the implementation of supply chain management could result on customers' satisfaction [7]. Customers' satisfaction is considered as immense capital for loyalty [8]. Accessible and accurate information could maximize the CRM [9].

Based on described background, the researchers proposed information system design based on locationbased service to improve services and to fulfill the requirements of stakeholders in blood management. The result of CRM system design is expected to enhance services as well as provide satisfaction to all donors in PMI.

\section{Research Methods}

Established system design is based on concepts of CRM as the integration of coordinated selling, marketing and service strategy [10]. Initial step is to find out customers' requirements toward established system. QFD and Kano model are employed as tools. QFD is defined as analysis tool to convince that development of products' features, characteristics and specification that covers manufacturing and required processes, has met the customers' necessities [11].

While, Kano model is described as theoretical model that connects requirements that supposed to be filled by a

*Corresponding author: agusmansur@uii.ac.id 
product or service with customer's satisfaction by identifying three types of necessities that could influence it, which are: must be requirement, one dimensional requirement and attractive requirement [12]. Second step is to determine technical requirement derived from voice of customers by using morphological chart. The final step is designing system data flow by applying Data Flow Diagram (DFD). DFD is considered as a method that describes data process flow from a system to its end [13].

\section{Result}

\subsection{Technical Requirements of the System}

Obtained Voice of customer will be graded by using Kano Model that implements Blauth's formula, later, several attributes that have influences toward customers' satisfaction will be selected. Attributes that are categorized as indifference will no longer be processed, as they have low influence on customers' dissatisfaction [14]. The result of Kano model will be the input for Quality Function Deployment (QFD) processing to translate costumers' requirements to company's technical requirements that also described by morphological chart stages to determine system's specification in detail. Hence, the aspects of system requirements are illustrated as follows:

Table 1. Morphological chart

\begin{tabular}{|c|c|c|}
\hline No & Function & Means \\
\hline 1 & $\begin{array}{l}\text { Providing appropriate } \\
\text { application's content }\end{array}$ & $\begin{array}{l}\text { Appropriate information } \\
\text { for donors' requirements } \\
\text { (information about } \\
\text { blood's stock, events, } \\
\text { history of blood's donor, } \\
\text { personal identification, } \\
\text { etc) }\end{array}$ \\
\hline 2 & $\begin{array}{l}\text { Presenting information on } \\
\text { blood's availability }\end{array}$ & $\begin{array}{l}\text { Entire information about } \\
\text { blood (type of blood, } \\
\text { rhesus, blood's } \\
\text { component) }\end{array}$ \\
\hline 3 & $\begin{array}{l}\text { Displaying information } \\
\text { status for donor activity }\end{array}$ & Available \\
\hline 4 & $\begin{array}{l}\text { Displaying notification } \\
\text { about information }\end{array}$ & $\begin{array}{l}\text { Only notification related } \\
\text { to information of } \\
\text { donor's events, routine } \\
\text { reminders, birthday } \\
\text { greeting and friends' } \\
\text { request }\end{array}$ \\
\hline 5 & $\begin{array}{l}\text { Integrated with blood's } \\
\text { supplier institutions }\end{array}$ & Local BDRS and UTD \\
\hline 6 & $\begin{array}{l}\text { Displaying accurate } \\
\text { information }\end{array}$ & All features \\
\hline 7 & $\begin{array}{l}\text { Requesting location } \\
\text { checking while } \\
\text { application is being } \\
\text { operated }\end{array}$ & Available \\
\hline
\end{tabular}

\begin{tabular}{cll}
\hline No & \multicolumn{1}{c}{ Function } & \multicolumn{1}{c}{ Means } \\
\hline 8 & $\begin{array}{l}\text { Recommending the } \\
\text { nearest location with } \\
\text { blood's supplier } \\
\text { institutions }\end{array}$ & Available
\end{tabular}

9 Recommended radius of $\leq 10 \mathrm{~km}$ from user's distance with blood's location supplier institutions

10 Providing information of

Available contact person and the nearest location of other Donors (other users)

11 Radius of recommended distance with the Donors

$\leq 10 \mathrm{~km}$ from user's location

12 Providing information and Available recommendation on an event and its nearest location

13 Recommended radius of the nearest blood donation event

14 Accomplishing user's account to improve privacy, data security and accessibility while operating information system of blood's donor

$\leq 25 \mathrm{~km}$ from user's location

Available, but optional so the users could access the application without user's account

15 Displaying profile picture on its information system's user account

16 Providing the features for utilization information

Help Menu
Available

C. Available




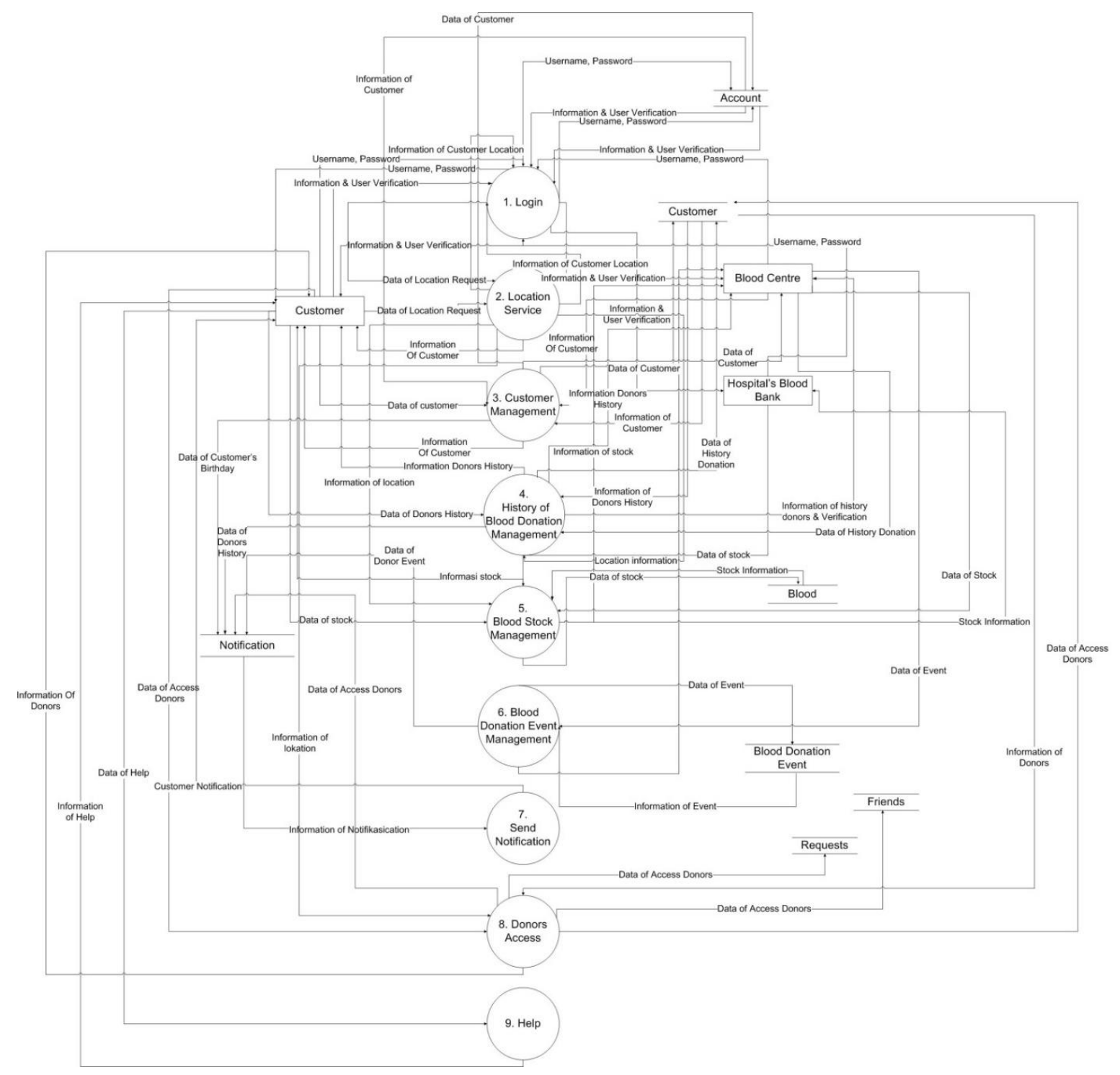

Fig 1. DFD Level 1

\subsection{Relations among Tables on Diagram}

Relation among tables for blood's donor information system is described on Figure 2.

\subsection{Description of System Design}

This information system ensures 5 features, which are: My profile that has specific function to identify customer's personal identification and history of blood's donation. Check stock is designated to check on recent blood's stock from available suppliers that completed with the nearest location recommendation from user's recent location. Donor's access is created to locate appropriate and the nearest donors for transfusion purpose. Event of blood donation is established to identify recent blood's donation activities based on location consideration and Help menu that functioned to assisst users in operating the information system.

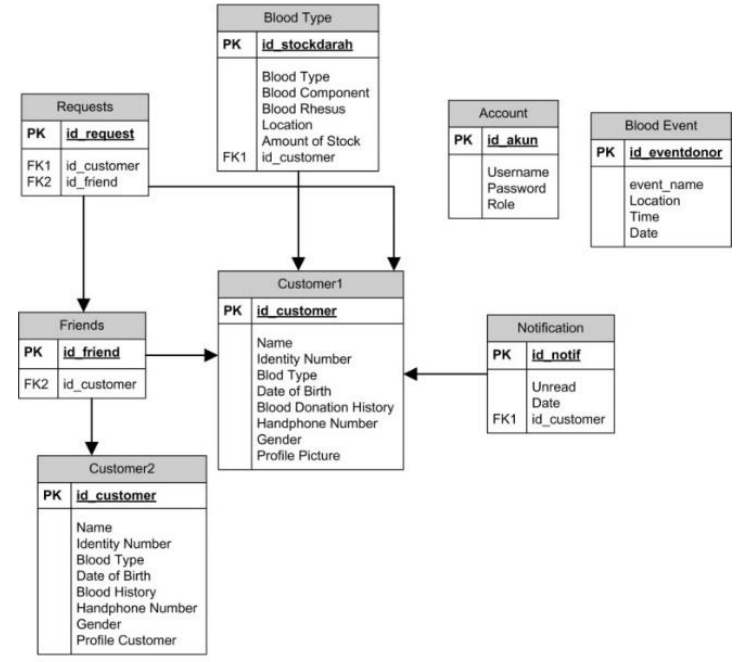

Fig 2. Entity relationship diagram 


\section{Conclusion}

Based on the results of the test which has been performed, it can be concluded as follows:

Producing shared information system that appropriates with donors' requirements and existing means, by diplaying information that adjusted with donor's requirement (availability information on blood's stock, information on events of blood donation, information on blood's donor history, personal identification, etc). Displaying information on blood's stock (type of blood, rhesus and blood's components), performing information status on donation schedule, notification that relates to blood's donation events, routine's reminder, birthday's greeting and feedback on application. Integration with local BDRS and UTD, announcing accurate information on all features, conducting location scanning when application is operated, recommending the nearest location with supplier institutions $\leq 10 \mathrm{~km}$ from user's location, providing information on contact person and recommending the nearest location of the donor $\leq 10 \mathrm{~km}$ from user's location, providing information related to blood's donation events by radius of $\leq 25 \mathrm{~km}$ from user's location, establishing user's account to improve privacy, data security and accessibility. Yet, this will be optional to allow users to be able to access the application without user's account. Displaying profile picture to ease the identity recognition and providing utilization assistance feature with Help menu.

\section{References}

1. Tribunnews, Indonesia Kekurangan Satu Juta Kantong Darah, Ini yang DilakukanATSI dan Kemenkominfo, (http://www.tribunnews.com/kesehatan/2016/02/15/i ndonesia-kekurangan-satu-juta-kantong-darah-iniyang-dilakukan-atsi-dan-kemenkominfo, 2016)

2. D. Widianto, Pasien RS Sardjito Dihimbau Minta Rujukan Darah ke PMI, (accesed from www.krjogja.com, 2015)
3. S.H. Stanger, R. Wilding, N. Yates, \& S. Cotton, What drives perishable inventory management performance? Lessons learnt from the UK blood supply chain. SCM: An. Inter. Jour 17/2, 107-123 (2012)

4. S. Lin, \& B. Lin,. Accessing information sharing and information quality in supply chain management. Decision Support Systems 42, 1641-1656 (2006)

5. S.X. Li Na, \& Z.M. Wei Yang, Decision Making Model Based on QFD Method for Power Utility Service Improvement. System Engineering Procedia 4, (2011)

6. R. Kalakota, \& M. Robinson, E - Business 2.0 Roadmap For Success. USA: Addison - Wesley (2001)

7. N. Kano, K. Seraku, F. Takahashi, S. Tsuji, Attractive Quality and Must-be Quality. The Jour of the Jpn Soci for Q C 14, 39-48 (1984)

8. E. Bendoly \& M. Swink, Moderating effects of information access on project management behavior, performance and perceptions. Jour of Op Mgmt 25, 604-622 (2007)

9. M. Rifai, Customer Relationship Management (CRM) dengan Blog. Elex Media Komputindo (2009)

10. R. Lupiyoadi, Intim dengan Konsumen. Jakarta: Salemba Empat (2013)

11. Indrajani, Perancangan Basis Data dalam Al lin 1. Jakarta: PT. Elex Media Komputindo (2011)

12. P. Gupta, Analysis of Customer Satisfaction of The Hotel Industry in India Using Kano Model \& QFD. Motilal Nehru National Institute of Technology (2012)

13. J. Belien \& H. Force, Supply Chain Management of Blood Products: A Literature Review. Eur J of Op Rrch (2012)

14. L. Cohen, Quality Function Deployment: How To Make QFD Work For You. New York: AddisonWesley Publishing Company (1995) 